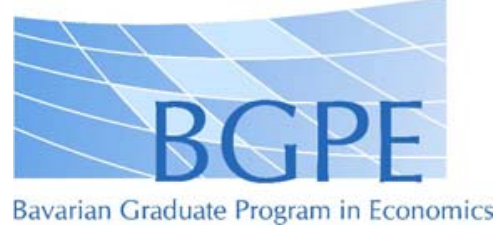

BGPE Discussion Paper

No. 54

\title{
Financial Incentives to Postpone Retirement and Further Effects on Employment - Evidence from a Natural Experiment
}

\section{Barbara Hanel}

May 2008

ISSN 1863-5733

Editor: Prof. Regina T. Riphahn, Ph.D.

Friedrich-Alexander-University Erlangen-Nuremberg

CBarbara Hanel 


\title{
Financial Incentives to Postpone Retirement
}

\section{and Further Effects on Employment -}

\section{Evidence from a Natural Experiment}

\author{
Barbara Hanel
}

May 26, 2008

This paper examines the effect of the introduction of permanent benefit reductions for early retirees (i) on the duration until retirement entry and (ii) on the duration until exit from gainful employment. I estimate discrete time duration models using different error term specifications. Administrative data containing the full earnings history of the individuals are used. Since the reform implementing the benefit reductions was a natural experiment, a true causal effect can be identified. The permanent reduction of retirement benefit amounts causes a postponement of retirement entry by about fifteen months and a delay of employment exit by about nine months on average.

Keywords: retirement insurance, labor force participation, natural experiment

JEL Keywords: H55, J26

Correspondence to:

Barbara Hanel

Department of Economics

University of Erlangen-Nuremberg

Lange Gasse 20

D-90403 Nuremberg

Germany

Tel.: $\quad+49-(0) 911-5302258$

Fax: $\quad+49$ - (0)911 - 5302178

E-mail: barbara.hanel@wiso.uni-erlangen.de 


\section{Introduction}

The pension systems of many industrialized countries are facing severe financial problems due to aging societies. Labor market and pension reforms were therefore implemented in several European countries to encourage labor force participation of the elderly. A longer working life would on the one hand reduce benefit payments per capita and it would on the other hand raise contributions. A frequently used policy measure that sets incentives to postpone retirement and to increase labor force participation is a benefit reduction for early retirees. ${ }^{1}$ However, especially older individuals may face employment restrictions, limiting their labor market opportunities. ${ }^{2}$ Therefore, an increasing duration until retirement does not necessarily imply that the duration until exit from gainful employment increases equivalently. This paper analyzes the effect of a pension reform in Germany that introduced permanent benefit reductions for early retirees. These reductions vary between $0.3 \%$ and $18.0 \%$ depending on the individual birth cohort and the timing of retirement. The reform is used to examine two issues: First, does the duration until retirement entry increase due to these benefit reductions? Second, does the duration until employment exit increase to the same extent? If the last month of employment and the first month of drawing benefits are not postponed to the same extent, there may be some relief for the retirement systems through benefit reductions, but the relief for the welfare state as a whole may be much smaller. It is therefore important to know to what extent a delay of retirement entry implies longer employment, too.

\footnotetext{
${ }^{1}$ See Council of the European Union (2003). Actuarially fair pension reductions for early retirees were implemented for example in Italy, Sweden, Austria, and Germany.

${ }^{2}$ See for example Hakola and Uusitalo (2005) or Dorn and Sousa-Poza (2007). Their findings are presented below in greater detail.
} 
The analysis shows that the reform causes an expected postponement of retirement by about fifteen months. Women and workers with low benefit entitlements delay retirement by more than men or those with high benefit entitlements. At the same time, the expected duration until exit from gainful employment increases by about nine months. The second effect is stronger for men and for individuals with high benefit entitlements.

Unlike previous studies on the effect of pensions in Germany ${ }^{3}$ I utilize a natural experiment and can therefore identify a true causal effect. The analysis sample is drawn from a new data set that provides very detailed information concerning the full employment history and the full earnings history of more then 60,000 individuals. This study appears to be the first one evaluating worker responses to this very recent reform.

The paper is organized as follows: In the next section, the German retirement benefit system and the recent reform are described in some detail, section three discusses the relevant literature and derives hypotheses. Section four describes the empirical strategy for estimating the effects of the reform on the duration until retirement entry as well as on the duration until employment exit. Section five presents the data. In section six the results of these two parts of the analysis are discussed. Section seven concludes.

\section{The Recent Pension Reform in Germany}

The public retirement insurance is the main income source for elderly individuals in Germany - about $80 \%$ of the average retiree’s income derives from claims to benefits (see Council of the European Union (2003)). Nearly 80\% of the labor force is covered by

\footnotetext{
${ }^{3}$ See for example Berkel and Börsch-Supan (2004) or Siddiqui (1997).
} 
the public retirement insurance. ${ }^{4}$ The retirement insurance is organized as a pay-as-yougo-system. Individual benefit claims depend on the individual earnings history. The minimum age for retirement entry is 65 years as a matter of principle, but since 1972 there were several exceptions from that minimum age for certain groups of insured workers. To allow a "flexible retirement entry", unemployed persons, women, and disabled individuals who meet certain criteria concerning their employment history could retire between age 60 and age 65, while the long-term insured with more than 35 years of contribution could retire between age 63 and age 65 . There were no benefit reductions following retirement prior to age 65 for those groups until 1997, and thus there was a strong incentive to retire at the earliest possible point in time. For example, about 79.9\% of the men and $47.4 \%$ of the women born in 1931 started to draw benefits before 1996, i.e. before the regular retirement age of 65 years (Deutsche Rentenversicherung Bund (2006)).

In order to reduce these incentives, the "Act on the Promotion of Growth and Employment” (Wachstums- und Beschäftigungsförderungsgesetz) was passed, which introduced benefit reductions for workers retiring prior to the age of 65, starting in 1997. The minimum age at which full pensions can be claimed was raised to age 65 for all insured workers. The implementation of the reform stretches over a long period, as the minimum age for receiving a full pension was increased in monthly steps over several years. Thus, in a transition period (1997 to 2005), different birth cohorts could retire with a full pension at different ages. For example, individuals born in January 1938 aged 61

\footnotetext{
${ }^{4}$ Civil servants and in some cases self-employed workers are not mandatorily covered.
} 
years and one month can receive "old-age pension for the unemployed" with full benefits. Individuals born in February 1938 can receive the full pension when they are 61 years and two months old, and so on. As a further consequence of the reform, prior to the cohort-specific regular retirement age, benefits can only be claimed at the price of a permanent benefit reduction. Figure 1 illustrates the retirement options for the transition cohorts (1937-1945). For every month that retirement entry takes place prior to the age of eligibility for the full pension, the benefits are reduced by 0.3 percentage points. Hence, given a specific retirement age, different birth cohorts have to accept different reduction rates. For example, a person starting to receive "old-age pensions for the unemployed" at age 61 and one month suffers no benefit reduction if born in January 1938, since for this cohort the age of 61 and one month is the age of entitlement for full benefits. But persons born in January 1940 with the same retirement decision would have to accept a reduction of $7.2 \%$. In that case, the minimum age of entitlement for full benefits is 63 years and one month, and 24 months of $0.3 \%$-points reduction accumulate. This regulatory framework allows one to identify the effect of payment reductions on the retirement decision.

\section{Literature and Hypotheses}

There is a large literature pointing out the importance of pension amounts and in particular pension accruals for the timing of retirement. Classical life-cycle-models used for example by Gordon and Blinder (1980) or Gustman and Steinmeier (1986), as well as option value models as established by Stock and Wise (1990), show that the actuarial unfairness of public and private pension benefits affects early retirement. If there is no reduction in benefit amounts corresponding to the extended period of benefit receipt, additional employment decreases the expected stream of future pension payments. 
Consequently, employment becomes an unfavorable choice for older workers. There are numerous empirical analyses using reduced form models which support these findings: The importance of social security benefit levels for retirement entries are e.g. shown by Blau (1994), while the relevance of benefit accrual through further employment is examined for example by Fields and Mitchell (1984) or by Coile and Gruber (2000), who apply the concept of the option value. Krueger and Pischke (1992), who examined a natural experiment in the US, found small but significant effects of social security benefits on the trend to retire early. ${ }^{5}$ Also, studies for Germany found a positive impact of pension reductions for early retirees on labor force participation. Berkel and BörschSupan (2004) simulated the effect of actuarially fair payment reductions on the retirement decision through changes in the option value. Siddiqui (1997) estimated hazard rates into retirement depending on future income streams. Both studies found that the duration until retirement entry significantly increases when early retirees face pension reductions. A similar effect is therefore expected for the recent reform: Individuals with a high minimum age of full benefit claims should retire later (i.e. they stay in the labor force for a longer period of time) than individuals with a low minimum age of full benefit claims. In other words, the duration from the first month of benefit eligibility until the actual retirement entry should - ceteris paribus - increase with the payment reductions.

But what will be the effect of increasing labor force participation on actual employment and the duration until employment exit? Will e.g. an unemployment spell between employment exit and retirement entry emerge or be widened? Individuals who

\footnotetext{
${ }^{5}$ They examined a social security reform in 1977 in the U.S. that reduced benefits for individuals born in 1917 or later, while benefits remained constant for older cohorts.
} 
want to maximize their expected lifetime utility from leisure and income face several options. It may be optimal for some individuals to postpone retirement in order to avoid permanent benefit reductions and the resulting reductions in future income streams, but to exit employment anyway, in order to increase current and future utility from leisure time. There are several possible income sources besides labor income and retirement benefits to finance consumption in the time between employment exit and retirement entry: Individuals may dissave, receive private transfers, or try to apply for minimum assistance, unemployment benefits, or other public income transfers. In many European countries, including Germany, systematic interdependencies of the eligibility for retirement and unemployment benefits exist that to some extent allow a substitution of those programs. Eased eligibility for pre-retirement in case of unemployment is often a part of public retirement programs. For example Portugal, Finland, Germany, Belgium, or the Netherlands provide displaced workers with public retirement benefits or public subsidies for pre-retirement in the framework of industrial agreements (European Commission (2006)). Likewise, longer or eased eligibility for unemployment benefits for older workers near retirement is very common across Europe. Such regulations can be found in nearly every member state of the EU and even in Switzerland. The actuarial adjustment of retirement benefits, intended to set incentives for continuing work, could hence be avoided rather easily by switching into other social security programs instead of early retirement.

Besides preferences for leisure, a lack of available jobs may cause the employment exit of older workers irrespective of the timing of retirement entry. Older worker's exit from employment is not always "voluntary" but often driven by 
employment constraints. There is a growing literature that distinguishes between "voluntary" and "involuntary" withdrawal from the labor force. ${ }^{6}$ Dorn and Sousa-Poza (2007) for example find that strict employment protection regulation and increasing unemployment rates increases the fraction of early retirees reporting their decision for early retirement as "involuntary”. Chan and Huff-Stevens (2002) find for the US that the effect of displacement on the probability of early retirement significantly exceeds the effect explained by the subsequent changes in the option value, i.e. the incentives relevant for the employee. Hakola and Uusitalo (2005) examine a reform in Finland, where the employer's contributions to the unemployment insurance are experience rated: If an employer displaces an employee who receives a pension for the unemployed afterwards, the employer has to pay higher contributions to the unemployment insurance in the future. In a reform in 2000, the sensitivity of contributions to past displacements was raised. Such a rise in the employer's liability for pension benefits significantly reduced the share of employees retiring early. This research suggests that at least some older workers would leave employment because they do not have the opportunity to stay in their current (or in a comparable) job and would not do so otherwise. In that case, again some individuals may postpone retirement in order to avoid permanent benefit reductions, but stop employment anyway due to a lack of demand for their labor. In the time between employment exit and retirement entry, a period of e.g. unemployment benefit receipt may occur. But regardless whether one considers "individual preferences

\footnotetext{
${ }^{6}$ Of course, "involuntary" does not mean that the decision is enforced, but that there are no jobs available which are sufficiently attractive to prevent workers from stopping employment. The distinction between "preferences for leisure" and "attractiveness of employment" is, of course, not very explicit. The decision to accept or reject a job opportunity is naturally based on the interaction of preferences and job characteristics, such as wages.
} 
for leisure" or "a lack of attractive job opportunities" as the main reason, employment exit and retirement entry must not be postponed to the same extent. Therefore, the effect of the reform on both decisions has to be analyzed separately to estimate the reform's total effect on the system of social security.

\section{Estimation Strategy}

The key issue of interest is the effect of payment reductions on the duration until retirement entry. This is initially estimated in the framework of a survival analysis, which considers every individual from the first moment "at risk" (i.e. the first moment a person is eligible for early retirement benefits) until retirement entry.

The data contains monthly information, and I find a considerable accumulation of retirement entries particularly in the first month after reaching eligibility. ${ }^{7}$ Hence, continuous time models are inappropriate due to a large number of tied observations. To solve this problem, discrete time models are used.

Let $T$ be a random variable measuring the duration until retirement entry in months. The probability of retiring before month $t+1$ is described by the probability distribution $F$, the probability of retiring within month $\mathrm{t}$ is given by the density function $\mathrm{f}$ and $\theta$ describes the probability that an individual retires in month $t$ given the spell did not terminate before.

$$
\begin{aligned}
& F(t)=\operatorname{Pr}(T \leq t), \\
& f(t)=\operatorname{Pr}(T=t),
\end{aligned}
$$

\footnotetext{
${ }^{7}$ In fact, about $68.4 \%$ of the observed spells end in the first month, while another $6.1 \%$ end after twentyfour, thirty-six or sixty months after reaching eligibility.
} 


$$
\theta(t)=\operatorname{Pr}(T=t \mid T \geq t)
$$

The survivor function provides the probability that an individual will "survive" month $t$, i.e. will retire at month $t+1$ at the earliest: $S(t)=1-F(t)=\operatorname{Pr}(T>t)$. It can be expressed in terms of $\theta$ as

$$
\begin{aligned}
& S(t)=\prod_{\tau=1}^{t}(1-\theta(\tau)), \text { while } \\
& f(t)=\theta(t) \cdot \prod_{\tau=1}^{t}(1-\theta(\tau)) .
\end{aligned}
$$

The likelihood contribution of an observed individual $i$ who retires in month $t$ is $f(t)$, while the likelihood contribution of a right-censored spell observed until month $t$ corresponds to the survivor function $S(t)$.

There are various possibilities for the specification of the function $\theta(t)$. The logistic model specifies

$$
\theta\left(t \mid x_{i}\right)=\frac{\exp \left(\alpha(t)+\beta^{\prime} x_{i}(t)\right)}{1+\exp \left(\alpha(t)+\beta^{\prime} x_{i}(t)\right)},
$$

where $x_{i}(t)$ are observed characteristics of individual $i$ that can be time-varying or constant over time. The vector $\beta$ is a parameter vector and $\alpha(t)$ is a period-specific effect that is constant across individuals and measures the effect of "being in month $t$ " on the conditional probability of retirement.

The likelihood function of this duration model is identical to the likelihood function of a binary logit model. Similarly, a binary probit model results if the spell lengths are assumed to follow a standard normal distribution: 


$$
\theta\left(t \mid x_{i}\right)=\Phi\left(\alpha(t)+\beta^{\prime} x_{i}(t)\right) .
$$

A third possibility is to specify a continuous-time proportional hazard rate as is done in Cox regressions and to modify it for the discrete framework. Let $U$ be a continuous random variable measuring the duration until retirement, with probability density function $g(u)$ and probability distribution $G(u)$, while the survival function conforms to the converse probability $H(u)=1-G(u)$. The hazard rate, the continuous-time equivalent to $\theta(t)$, is

$$
\lambda(u)=\lim _{\Delta \rightarrow 0} \operatorname{Pr}\left(u \leq U<u+\Delta \mid U \geq u, x_{i}\right) / \Delta .
$$

The relationship between the hazard rate, the density function and the survivor function can be described as:

$$
\begin{aligned}
& \lambda(u)=g(u) / H(u) \text { and } \\
& H(u)=\int_{0}^{u} \exp (\lambda(\tau)) d \tau .
\end{aligned}
$$

In proportional hazard models, the hazard rate is typically specified as $\lambda(u)=\lambda_{0}(u) \cdot \exp \left(\beta^{\prime} x_{i}(u)\right)$. Now consider again the discrete-time framework, where duration until retirement is measured in discrete intervals. $\theta(t)$, the probability of retiring in month $t$, i.e. the interval $[t, t+1)$, conditional on surviving until month $t$ can be expressed in terms of the continuous $\lambda(t)$ in the following way:

$$
\operatorname{Pr}(t \leq U<t+1 \mid U \geq t)=\frac{H(t)-H(t+1)}{H(t)}=1-\frac{\exp \int_{0}^{t+1} \lambda(\tau) d \tau}{\exp \int_{0}^{t} \lambda(\tau) d \tau}=1-\exp \int_{t}^{t+1} \lambda(\tau) d \tau
$$


Substituting the specification of $\lambda$ as proportional hazard and assuming $x_{i}(t)$ to be constant over $[t, t+1)$ yields

$$
\theta(t)=1-\exp \left(\exp \left(\beta^{\prime} x_{i}(t)+\alpha(t)\right)\right)
$$

with $\alpha(t)=\ln \int_{t}^{t+1} \lambda_{0}(\tau) d \tau$. The proportional hazard model for discrete time thus reduces to a complementary log-log model with extreme value distributed spell lengths. ${ }^{8}$ In the analysis, the three described models (logit model, probit model and complementary log-log model) for estimating the transition rate $\theta(t)$ are estimated side by side to check for distributional dependency of the results. Due to the panel structure of the data, the error terms may not be independent. Hence, the standard errors are clustered to account for intra-person correlation.

All models allow for a very flexible form of duration dependence, since $\alpha(t)$ can be specified as a set of dummy variables indicating a specific month after starting to be at risk. In a more parsimonious specification $\alpha(t)$ can also be specified as a linear, quadratic or other arbitrary function of duration.. To allow maximum flexibility, a set of dummy variables was used at last to represent the duration of the spell.

The key explanatory variable in the vector $x_{i}(t)$ is the rate of payment reductions at any month if the person were to retire in this month. Since the pension reform is a kind of natural experiment and the rates of payment reductions at a given age are exogenous only determined by the birth cohort of an individual-, the marginal effect of the rate of payment reductions on the transition rate $\theta(t)$ can be interpreted as a causal effect.

\footnotetext{
${ }^{8}$ For a detailed presentation of the discrete time proportional model see Meyer (1990).
} 
Nevertheless, a necessary assumption for identification is that there are no non-ignorable factors determining the retirement behavior that coincide with the reform process. In other words, (i) factors possibly affecting the retirement decision that may differ between neighboring birth cohorts have to be controlled for, and (ii) one has to assume that the effect of these factors remains constant over the reform process.

If there is any variable which is changing between neighboring birth cohorts that is important for the retirement decision but cannot be controlled for in the model, the effect of the reform would not be identified. The model therefore controls for personal characteristics and the labor market situation, which could possibly affect the retirement decision, such as the amount of benefits, unemployment, or health problems. They are presented in detail in section five, where the data are described. As mentioned above, one has to assume that the effect of the controlled variables remains constant over the observed birth cohorts. If they were changing over cohorts (as the reduction in payments), the causal effect of payment reductions would not be identified. However, the relevant observed birth cohorts are 1937 to 1942 (see section 5), which is a rather short period. There is no obvious reason to assume that their response e.g. to unemployment or health problems should vary.

For a deeper insight in the sensitivity of different population groups to the reform, the estimation is implemented also for different sub-samples: For men and women, for men in the East and the West, and for men in the West subdivided by quintiles of full benefit claims calculated for an assumed retirement entry at age 60. A higher effect of payment reductions in a population group then indicates a higher sensitivity to the reform. 
The duration until employment exit is modeled nearly identically. I examine the duration until the last month of employment instead of the duration until the first month of retirement. Again, transition rates were estimated with logistic, standardnormal and extreme value distributed spell lengths, and standard errors were adjusted for intra-person correlation. Duration dependence is modeled using a set of dummy variables as in the models above. The model further controls for personal characteristics and the labor market situation. The most important explanatory variable is again the rate of payment reductions relevant for the individual at any given point in time.

\section{The Data}

The data are provided by the German public retirement insurance. For the analysis, the so-called "Versicherungskontenstichprobe 2002" (sample of social insurance accounts) is used. The benefit entitlements of all individuals who ever held a job subject to compulsory retirement insurance and who are still alive are administered by public insurers using a personal account. The data set is a random sample of all accounts existing in 2002. ${ }^{9}$ It contains the complete employment and earnings history (as relevant for benefit claims) for 64,538 individuals and therefore the potential social security entitlements since the age of 14 until 2002, on a monthly basis. Furthermore, some socioeconomic characteristics are available in the dataset (see below). The main advantages of these administrative data are:

· there is no panel attrition,

\footnotetext{
${ }^{9}$ The data are collected for administrative purposes and the editing for research needs is in progress. Samples of subsequent years were therefore not available at the time of the analysis.
} 
- there is no recall bias in the employment and earnings history,

- $\quad$ and there are only few missing values.

Since exit from employment due to old age and entry into retirement prior to the regular minimum age of 65 is estimated, for this analysis only persons are considered, who

- were employed for at least one month at age 55 or afterwards, and

- meet the necessary conditions concerning their employment history to claim a pension before the age of 65 (and were therefore affected by the reform). ${ }^{10}$

This holds for 26,246 individuals. This sample of individuals is used for the estimation of the duration until retirement entry as well as until employment exit. For the latter, all observations from age 55 onwards are used. They are censored after the last observed employment exit (for the exact definition see below). The final sample comprises 1,457,173 person-month observations out of which 22,413 exits from employment were observed in the period from 1995 until 2002. For the estimation of the duration until retirement entry all observations from the first month of eligibility onwards were used and they are censored after retirement entry (see below). In the end, 302,249

\footnotetext{
${ }^{10}$ Persons who had the possibility to claim a pension before the age of 65 were: (i) women aged 60 years and above, with more than fifteen years of compulsory contributions after the age of 40 (they can apply for "women's old-age pension"), (ii) individuals aged 63 and above, with more than 35 insurance years (they can apply for "pension for the long-term insured") and (iii) unemployed workers who are at least 60 years old, with at least fifteen insurance years, and who contributed to the retirement insurance for more than eight out of the last ten years (they can apply for "pension for the unemployed"). Of course, the sub-sample of unemployed individuals is not a random sample of all insured individuals. In order to avoid endogenous sample selection, the analysis is therefore (deviating from the legal definition) not constrained to the actually unemployed: every person is considered to be eligible for a "pension for the unemployed" who meets the necessary employment history requirements, regardless of whether he or she is unemployed or not. It is possible that the reaction to the reform is therefore underestimated, since some workers are included in the analysis sample who are in fact not affected by the reform and cannot respond. This however is not problematic inasmuch as the results below can be interpreted as a lower bound of the underlying effects.
} 
person-month observations are available for that part of the analysis, and 21,053 entries into retirement are observed.

For both parts of the analysis, the dependent variable is derived from the current employment status of an individual at a given point in time. For the estimation of the hazard rates of a transition to retirement, a dummy variable is constructed indicating whether a person receives an old-age pension in a given month or not. Other possible definitions of retirement such as a self-reported employment status or an indicator using the number of hours worked are not reasonable, since the main focus of this analysis are the reform's effects for the retirement insurance. The dependent variable, indicating retirement entry, takes the value one in the first month when retirement was observed and zero otherwise. For the second part of the analysis I use a dummy variable indicating whether an individual is employed or not. Again, employment is defined in the legal sense since this is the definition of interest from the insurer's point of view. Therefore, employment that is not subject to compulsory social security contributions is not taken into account. ${ }^{11}$ The last month in which employment is observed is the employment exit. So, a change from employment to non-employment is not defined as employment exit if employment is observed again later on. The dependent variable takes the value one in the month of employment exit and zero otherwise.

As discussed in section four, the rate of reduction in payments is the key explanatory variable for the estimation of transitions into retirement as well as for the estimation of transitions out of employment. At every point in time, the current rate of

\footnotetext{
${ }^{11}$ At the time of the survey no contributions had to be paid up to a monthly wage of $400 €$.
} 
reduction in payments is calculated that an individual would suffer when she were retiring instantaneously. Prior to the first month of eligibility for retirement benefits no such reduction rates are available per definition. Since observations prior to the first month of eligibility are used for the analysis of employment exit, the individual rate of payment reductions relevant at that first month of eligibility is used for the time before eligibility. The effect of payment reductions on the hazard rate out of employment is allowed to change after reaching eligibility.

Besides the rate of reduction in payments, some socio-economic characteristics that could possibly affect the retirement or the employment decision are used for the estimation of the hazard rates into retirement. These are the amount of benefits if the person could receive a full pension (which is determined by the labor earnings history) as well as the interaction with the reduction in payments. Furthermore, some taste shifter variables - namely education, occupation, gender, children ${ }^{12}$, and nationality, whether a person faces health problems ${ }^{13}$, and whether a person comes from East or West Germany $^{14}$ - are included in the model. ${ }^{15}$ Moreover, the annual unemployment rate by occupation ${ }^{16}$ is included to control for the overall labor market situation.

\footnotetext{
${ }^{12}$ In addition to acquiring benefit entitlements by paying earnings-related contributions, some benefits are credited for rearing a child regardless of whether contributions are paid during this time. But only the parent who is mainly concerned with child rearing can get these benefits. The data only includes children relevant for benefits. Therefore the model in fact does not control for having a child, but for having raised a child.

${ }^{13}$ Individuals are defined to face health problems if they were ill and therefore not able to work for a period of at least two months in the last three years. To test for robustness, four additional definitions were used. The results did not differ substantially and are available from the author upon request.

${ }^{14}$ An individual is defined to be East German, if he or she is entitled to benefits due to employment spells in the former GDR.

${ }^{15}$ Other determinants of labor market behavior are the spouse's income and own and spouse's assets. Unfortunately, the retirement insurers do not collect information on assets. Information on spouse's
} 


\section{Results}

All estimations and additional calculations are executed for the entire sample as well as for men and women separately. Furthermore, separate estimations were generated for men from East and West Germany and for men in the West subdivided by quintiles of full benefit claims calculated for an assumed retirement entry at age 60. I first report the results for the entire population and will then discuss differences between population groups.

Figures $2 \mathrm{a}$ and $2 \mathrm{~b}$ depict the observed transition rate into retirement by duration of spells and the observed transition rate out of employment, respectively. Furthermore, the average transition rates predicted by the logit, probit and proportional hazard model are shown. The models fit the data well. The distinct peaks in the transition rates at the regular retirement age 65 and at the minimum ages for receiving reduced benefits at age 63 and age 60 are replicated by the estimated transition rates.

Since the coefficients of the nonlinear models are difficult to interpret, the marginal effects of changes in explanatory variables were calculated for every individual and then averaged over the entire sample. The standard errors of the marginal effects were bootstrapped. ${ }^{17}$ Tables $1 \mathrm{a}$ and $1 \mathrm{~b}$ display these average marginal effects of personal and labor market characteristics on transition rates into retirement and out of employment. The marginal effects estimated with the proportional hazard model are

earnings are not provided for the sake of data privacy. However, it seems reasonable to assume that the birth cohorts 1937 to 1942 do not differ substantially in these variables.

16 To test for robustness, different measures of unemployment were used, including unemployment by education, gender, and region. The results differ only slightly and are available from the author upon request.

${ }^{17}$ The central computing facilities did not allow for more than 80 draws. 
slightly lower than the ones estimated with Logit and Probit, but they do not differ substantially. We see that men have a lower transition rate into retirement, so they tend to retire later than women, and the transition rates for individuals from East Germany are slightly higher than for West German individuals, but the effect is small. The same is true for transitions out of employment (see Table 1b). Persons with health problems retire and leave employment earlier than persons in good health, as could be expected. The same is true for a high unemployment rate, which apparently pushes workers into early retirement and out of employment. High benefit entitlements are connected to a shorter period between eligibility for benefits and retirement entry, but have nearly no marginal effect on the transition rates out of employment. The marginal effect of the benefit reduction rate has the expected sign for both transitions. Raising the rate of monthly reduction in payments by $0.1 \%$-point decreases the conditional probability to retire in month $t$ by 0.035\%-points (probit model) to $0.037 \%$-points (proportional hazards model) on average. The average observed transition rate into retirement was $6.965 \%$, so an increase in the reduction rate of $0.1 \%$-points reduces the hazard rate on average by about $0.5 \%$. Surprisingly, the estimated average marginal effect on the transitions out of employment is of much higher magnitude.

In addition to the estimation of average marginal effects, the total effect of the reform was simulated to shed further light on that issue. First, for every person at every observed point in time, a transition rate into retirement (and out of employment) was predicted without reduction in payments. Second, the transition rate was predicted given the reduction rate after full implementation of the reform. The results by gender are presented in Table 2, based on separate estimations for men and women. For men the 
average monthly transition rates into retirement were reduced by about $40 \%$ from $5.3 \%$ before the reform to $3.2 \%$ after the reform in all three models, and the effect is highly statistically significant. The effect is much stronger for the female population. While the monthly transition rates into retirement for women were about $14 \%$ before the reform, they were reduced to nearly a fifth after the reform, resulting in transition rates of 2.5\%$3 \%$ depending on the model used. In contrast to the average marginal effects reported above, the whole effect of the reform on the transitions out of employment is much smaller than on the transitions out of retirement, as expected. Nonetheless, at least for men the effect is also considerable and highly statistically significant. Transition rates out of employment were reduced by the reform from $1.8 \%$ to $1.5 \%$. Nearly no effect is found for women.

Since changes in transition rates are not easy to interpret, the average survivor function was calculated based on predicted individual transition rates. Figure 3 depicts the results. Nearly the entire population at risk is expected to exit employment and enter retirement until the age of 65, regardless of whether there are reductions in payments or not. Nevertheless, retirement is postponed to a substantial amount due to the reform. Without any reduction in payments, about $15 \%$ of the male and about $30 \%$ of the female population at risk retires instantaneously at the first month of benefit eligibility. Within the first six months of benefit eligibility, less than $50 \%$ of the male and less than $25 \%$ of the female population are still at risk. After the reform, for men as well as for women, about $75 \%$ of the individuals are still at risk after half a year, and it takes about three years for both sub-samples until half of the population at risk has retired. After the reform, men and women show a pattern of retirement entry that is much more similar to 
each other than before the reform, while the change in retirement behavior of women was much stronger.

For men, the reform also causes a postponed exit from employment. About 50\% of the male individuals at risk exit employment until the age of 60 when there are no reductions in payments. This share decreases to about $25 \%$ after the reform. After age 60 the effect disappears and becomes even slightly negative after age 61. For the female population on the other hand there is nearly no effect until age 60 and a slightly positive effect afterwards.

But besides the postponing of retirement and the slight postponing of employment exit, the time lag between exit from employment and entry into retirement is widened considerably. The distance between the survival function for exit from employment and the survival function for entry into retirement shows the fraction of the population at a given age that is not gainfully employed anymore, but not retired yet as well. That fraction clearly increases with the reform for both men and women. For example, without the reform $42 \%$ of the male risk population is expected not to retire until age 61 , while $38 \%$ should not exit employment until the same age. Consequently, we expect to observe that $4 \%$ of the population permanently left employment but did not retire by age 61 . Due to the reform, this share increases to $22 \%$. The effect is even stronger for women: Without the reform survival until employment exit nearly perfectly mirrors the survival until retirement entry about half a year after age 60 . Full implementation then results in a huge gap between both. The fraction of the female population that permanently left the labor force but did not retire e.g. at age 61 rises from $1 \%$ to $44 \%$. 
Figure 4 clarifies that point. It shows the difference between the aggregate number of individuals who exited employment by a given age and the aggregate number of individuals who were retired by the same age, i.e. those individuals, who are not in employment (and do not reenter employment in the future), but receive no retirement benefits yet. ${ }^{18}$ Without the reform, in the second quarter of age 60 that number amounts to about 550.000 men and 180.000 women, respectively. It decreases to nearly zero until age 63 for men and even before age 61 for women. These numbers rise dramatically with fully implemented reform: At the age of 63, more than 600.000 men and also more than 600.000 women do not receive any retirement benefits although they already exited employment. Up to the age of 65 , there are still about 700.000 individuals out of employment for whom no retirement benefit receipt is observed, about one third of them are men. Immediately after the age of 65 , this number decreases to nearly zero. In sum, Figures 3 and 4 show: First, entry into retirement is postponed. Second, exit from employment is postponed as well. And third, the reform's effect on the employment decision is much smaller than the reform's effect on the retirement decision and consequently a time lag between employment exit and retirement entry emerges or is widened.

In a next step, the expected value of the average survivor function was calculated. Table 3 shows the expected duration until retirement entry and employment exit in months. The reform raises the expected duration until retirement by about 15 months.

\footnotetext{
${ }^{18}$ For the calculation of these aggregate numbers the number of observed individuals in the sample was extrapolated using expansion factors to get an estimate of the aggregate population at risk in the basic population. This aggregate population at risk was then assumed to decrease over time according to the predicted average survival function.
} 
This result is consistent with the simulations of Berkel and Börsch-Supan (2004) and Siddiqui (1997), who both predicted a shift in retirement entry of about one year if payment reductions of $0.3 \%$-points per month were introduced. At the same time, exit from employment is postponed as well. But the expansion of the expected spell duration until employment exit is only about nine months, so the gap between both events grows by about half a year due to the reform.

Table 3 presents additional results for population subgroups based on separate estimations. First, we see that women's reaction concerning the retirement decision is much stronger than the reaction of men. Women postpone their retirement entry by 27 to 32 months, depending on the model used, while the effect for men is only about ten months. Second, the reaction is somewhat stronger for East German men than for men from West Germany. And third, for the latter the reaction clearly decreases with growing benefit claims. Since the amount of benefits is determined by the earnings history, this indicates that men with higher lifetime wages react less than those with lower wages and/or those with a weaker attachment to the labor market. The opposite is true when we examine the effect on the employment decision. Now, the reaction of men is much stronger and increases with benefit claims, i.e. with the amount of lifetime earnings. The reform balances the duration until employment exit for individuals with high and low benefit claims, which is mostly due to a change in the employment decision of those with high lifetime earnings. Thus, the sensitivity to policy-induced incentives for a longer working life seems to be especially high in the groups with lower labor market attachment and probably lower chances to stay gainfully employed and vice versa. 
Apparently, there arises an employability-problem mainly for those individuals who show a strong response to the reduced provision of pension incomes.

\section{Conclusions}

A recent pension reform in Germany introducing permanent benefit reductions for workers retiring prior to the minimum age was used to examine the effects of pension reductions on the timing of entry into retirement and on the timing of employment exit. Since the reform was a natural experiment, the results can be interpreted as causal effects under weak behavioral assumptions. Administrative data containing the full earnings history of the individuals were used. The main advantage of this data set is that there is no panel attrition and no recall bias. The models are flexible in the specification of duration dependence and all results are robust against changes in distributional assumptions.

The reform had indeed a great influence on the employment and retirement decisions of older workers. After the reform, retirement entry occurs on average nearly fifteen months later, and at the same time workers are expected to stay in gainful employment about nine months longer. In some sub-groups the effect is even higher, and retirement is postponed for up to two and a half years, while employment spells increased by up to one year. Hence, there is a substantial gain for the retirement insurance, since the period of benefit payment is clearly reduced and the period of contribution payments is 
extended. ${ }^{19}$ Financial incentives to postpone retirement entry are a promising way to meet the financial challenge of longer life-expectancy for the old-age insurance.

However, since employment spells expand by less than retirement is delayed, periods of unemployment (or other non-employment) increase, too. In addition, sensitivity to this reform is very different across population groups. Women, East German men and workers with low benefits display the strongest response with respect to the retirement decision. Unfortunately, the same groups extend employment only by very little. Those groups who postpone retirement for an especially long time are also the ones who do not increase their time in employment equivalently. Consequently, the income situation of those individuals with limited employment opportunities appears to deteriorate. Further research is needed to quantify any distributional effects of the reform.

\section{References}

Berkel, B. and A. Börsch-Supan, 2004, Pension Reform in Germany: The Impact on Retirement Decisions, Finanzarchiv, Vol. 60, No. 3, 393 - 421.

Blau, D.M., 1994, Labor Force Dynamics of Older Men, Econometrica, Vol. 62, No. 1, 117-156.

Chan, S. and A. Huff-Stevens, 2002, How Does Job Loss Affect the Timing of Retirement?, NBER Working Paper Series No. 8780, Cambridge.

Coile, C. and J. Gruber, 2000, Social Security and Retirement, NBER Working Paper Series No. 7830, Cambridge.

Council of the European Union, 2003, Joint Report by the Commission and the Council on Adequate and Sustainable Pensions http://www.consilium.europa.eu/ueDocs/cms_Data/docs/pressdata/en/misc/75097.pdf (08/06/2007).

\footnotetext{
${ }^{19}$ Since the amount of benefits is reduced permanently if someone does not postpone retirement, the
} retirement insurance necessarily benefits from the reform, independent of the reaction of the insured. 
Deutsche Rentenversicherung Bund, 2006, Rentenversicherung in Zeitreihen, (Oktober 2006), DRV-Schriften Band 22, Berlin.

Dorn, D. and A. Sousa-Poza, 2007, 'Voluntary' and 'Involuntary' Early Retirement: An International Analysis, IZA Discussion Paper No. 2714, Bonn.

European Commission, 2006, Mutual Information System on Social Protection (MISSOC), Social Protection in the Member States of the European Union, the European Economic Area and in Switzerland - Comparative Tables

http://ec.europa.eu/employment_social/missoc/2006/tables_part_1_en.pdf (08/06/2007).

Fields, G.S. and O.S. Mitchell, 1984, Economic Determinants of the Optimal Retirement Age: An Empirical Investigation, Journal of Human Resources, Vol. 19, No. 2, 245 262.

Gordon, R.H. and A.S. Blinder, 1980, Market Wages, Reservation Wages, and Retirement Decisions, Journal of Public Economics, Vol. 14, No. 2, 277 - 308.

Gustman, A.L. and T.L. Steinmeier, 1986, A Structural Retirement Model, Econometrica, Vol. 54, No. 3, 555 - 584.

Hakola, T. and R. Uusitalo, 2005, Not so voluntary Retirement Decision? Evidence from a Pension Reform, Journal of Public Economics, No. 89, Iss. 11-12, 2121 - 2136.

Krueger, A.B. and J. Pischke, 1992, The Effect of Social Security on Labor Supply: A Cohort Analysis of the Notch Generation, Journal of Labor Economics, Vol. 10, No. 4, 412-437.

Meyer, B. D. (1990), Unemployment Insurance and Unemployment Spells, Econometrica, Vol. 58, No. 4, 757-782.

Siddiqui, S., 1997, Early Retirement in West Germany: A Sequential Model of Discrete Choice, Zeitschrift für Wirtschafts- und Sozialwissenschaften, No. 117, 391 - 415.

Stock, J.H. and D.A. Wise, 1990, Pensions, the Option Value of Work, and Retirement, Econometrica, Vol. 58, No. 5, 1151 - 1180. 
Figure 1 Age of Eligibility for Retirement Benefits (by Month of Birth)

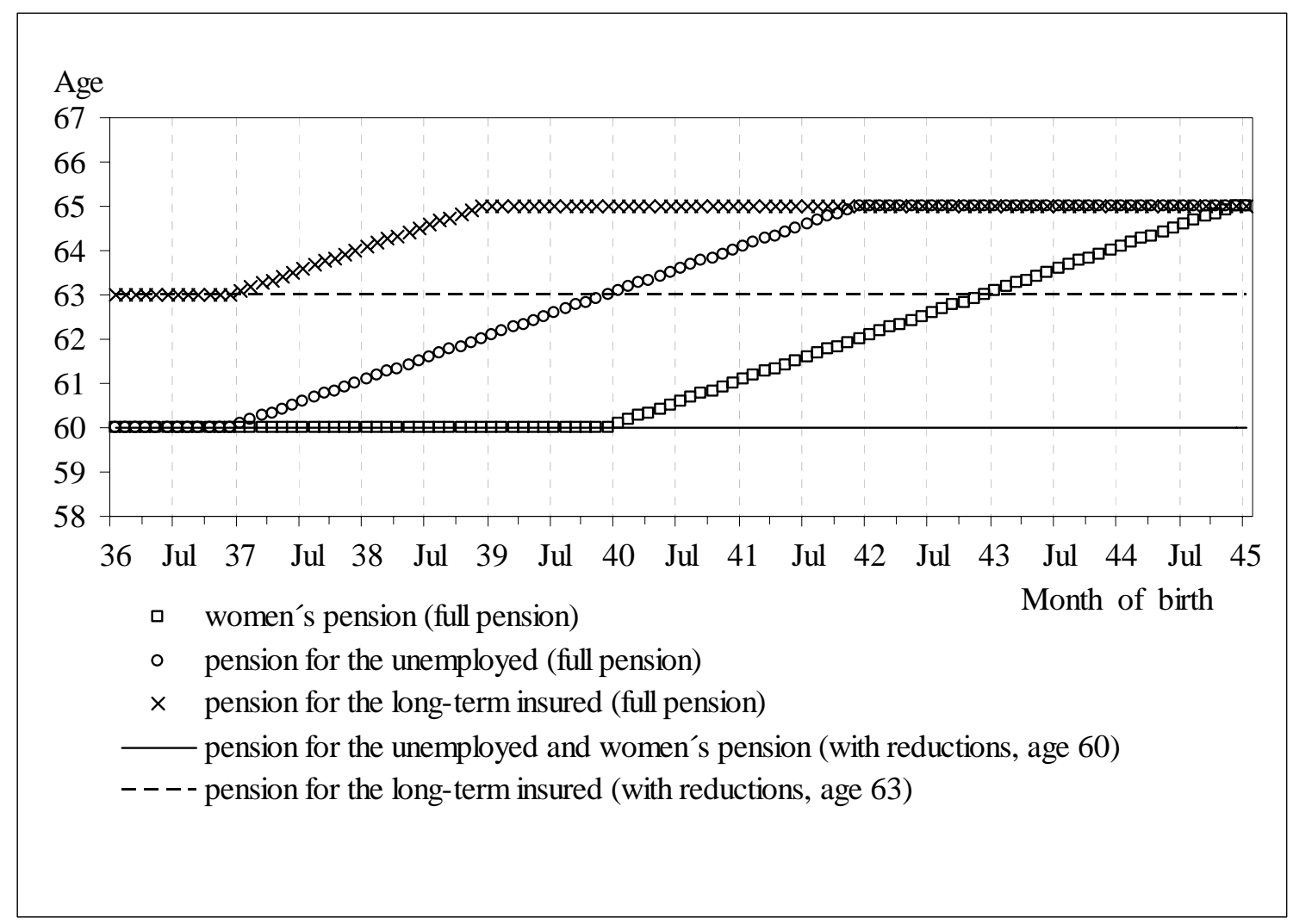

Source: Wachstums- und Beschäftigungsförderungsgesetz(1996), own illustration. 
Figure 2a Model Fit: Observed and Estimated Transition Rates Into Retirement

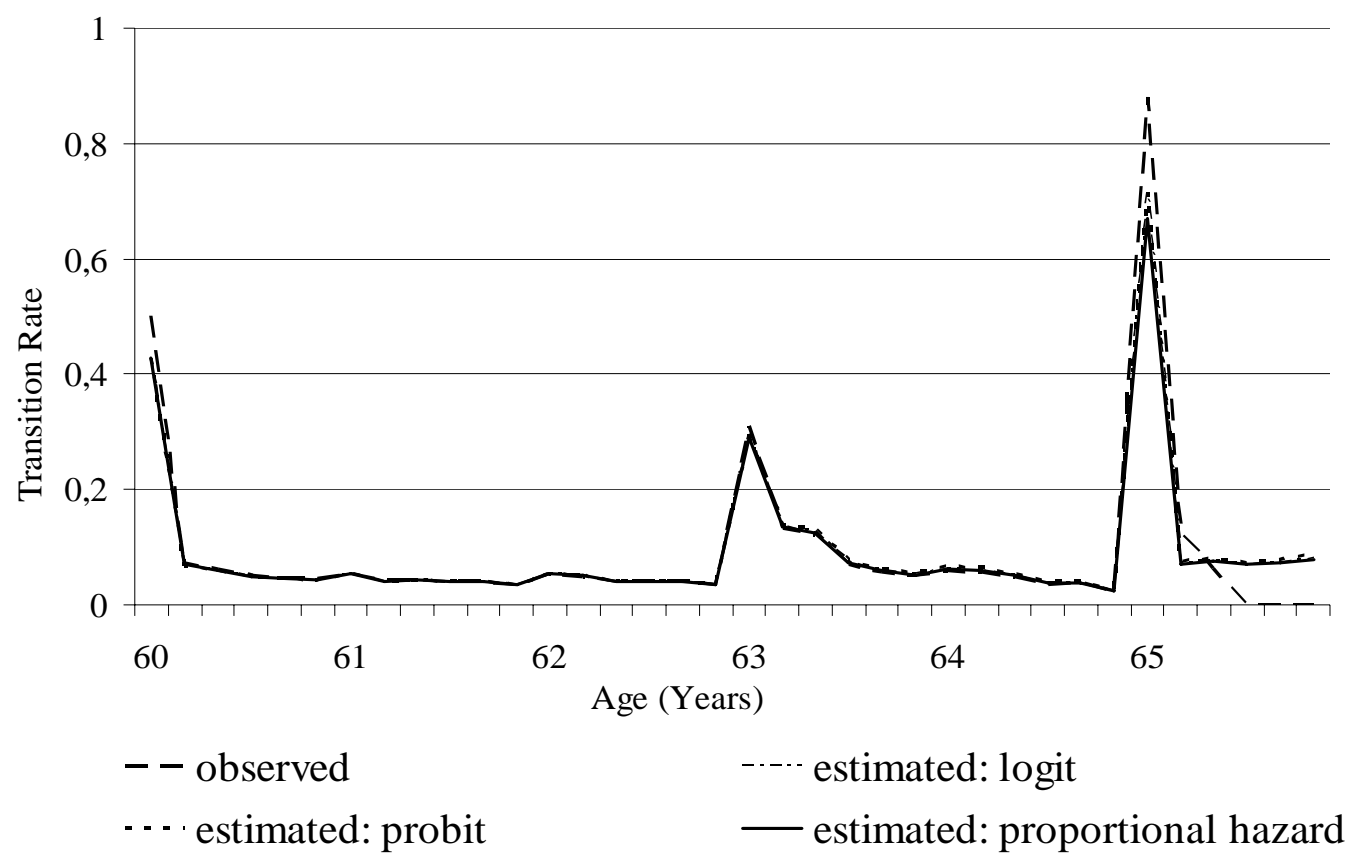

Figure 2b Model Fit: Observed and Estimated Transition Rates Out Of Employment

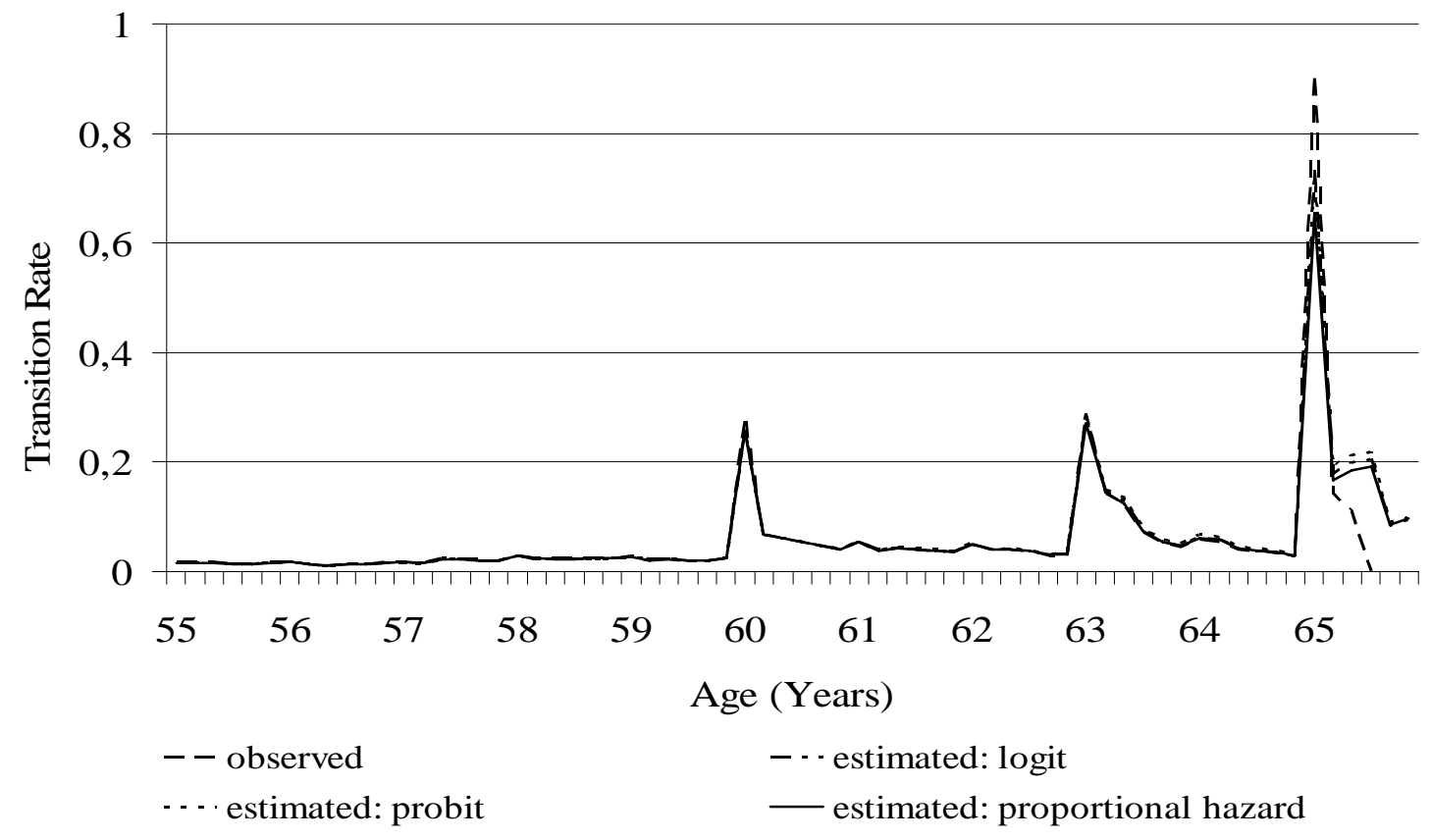

Source: Versicherungskontenstichprobe 2002, own calculations. 
Figure 3 Expected Survival Until Employment Exit and Expected Survival Until Retirement Entry Between 1995 and 2002: Population at Risk by Age
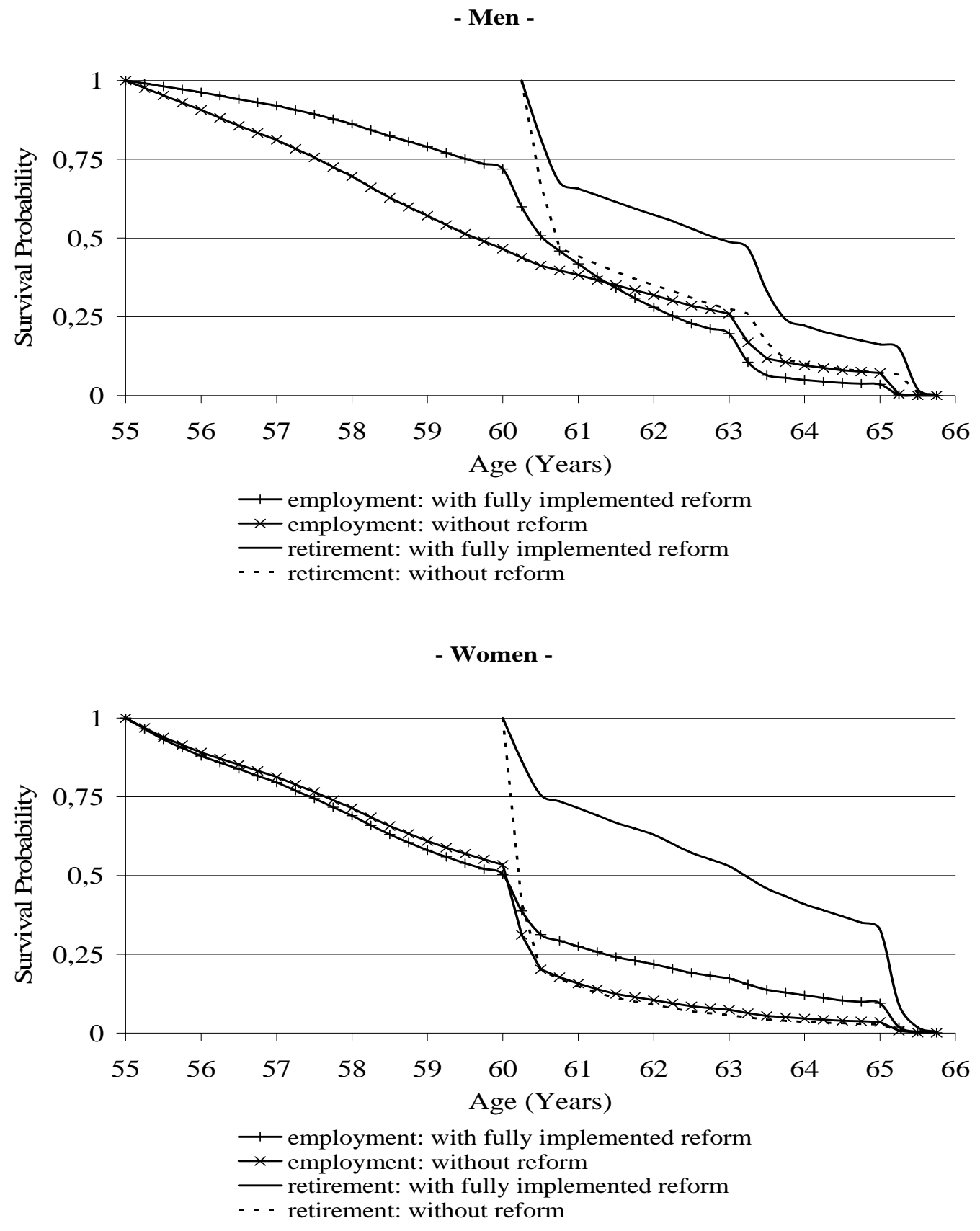

Source: Versicherungskontenstichprobe 2002, own calculations. 
Figure 4 Expected Number of Individuals Who Were Neither in Retirement Nor in Employment Between 1995 and 2002 by Age

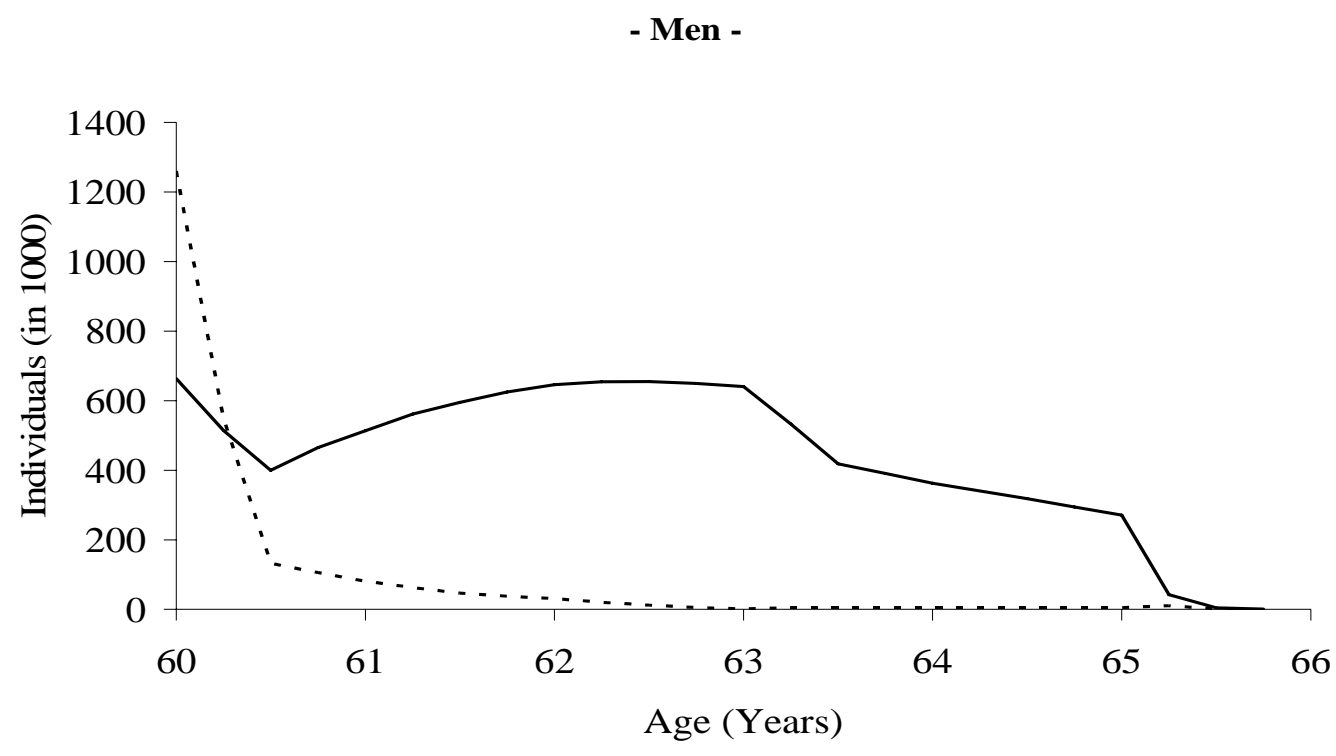

— with fully implemented reform -.. without reform

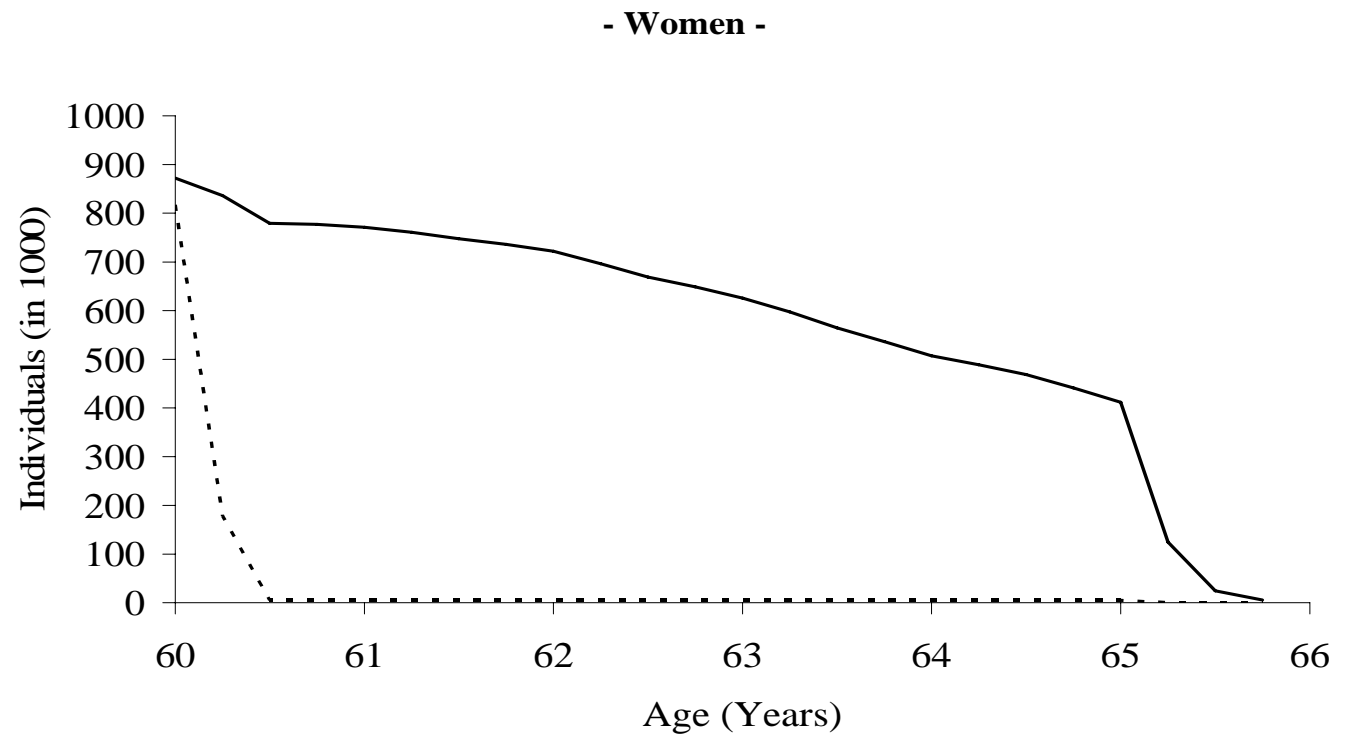

— with fully implemented reform $\quad$-. - without reform

Note: Due to the separate estimation of the number of individuals in employment and the number of individuals in retirement, negative values occured sporadically. In the above figure these negative values were set to zero.

Source: Versicherungskontenstichprobe 2002, own calculations. 
Table 1a Average Marginal Effects of Covariates on Transistion Rates Into Retirement

\begin{tabular}{|c|c|c|c|c|c|c|}
\hline & \multicolumn{2}{|c|}{ Logit } & \multicolumn{2}{|c|}{ Probit } & \multicolumn{2}{|c|}{ Proportional Hazard } \\
\hline $\begin{array}{l}\text { Average Predicted } \\
\text { Transition Rate Into }\end{array}$ & \multicolumn{2}{|c|}{0,06965} & \multicolumn{2}{|c|}{0,06962} & \multicolumn{2}{|c|}{0,06943} \\
\hline $\begin{array}{l}\text { Average Effect of Changes } \\
\text { in Dummy Variables }\end{array}$ & Effect & $\begin{array}{l}\text { Standard } \\
\text { Error }^{a} \\
\end{array}$ & Effect & $\begin{array}{l}\text { Standard } \\
\text { Error }^{a} \\
\end{array}$ & Effect & $\begin{array}{l}\text { Standard } \\
\text { Error }^{a} \\
\end{array}$ \\
\hline Individual... & & & & & & \\
\hline comes from East Germany & 0,00655 & 0,00081 & 0,00722 & 0,00085 & 0,00618 & 0,00080 \\
\hline is a foreigner & $-0,01280$ & 0,00107 & $-0,01249$ & 0,00103 & $-0,01285$ & 0,00106 \\
\hline has children & 0,00266 & 0,00136 & 0,00366 & 0,00138 & 0,00192 & 0,00130 \\
\hline is female & 0,03001 & 0,00163 & 0,03319 & 0,00168 & 0,02779 & 0,00155 \\
\hline faces health problems & 0,02438 & 0,00159 & 0,02673 & 0,00166 & 0,022414 & 0,001539 \\
\hline $\begin{array}{l}\text { Average Marginal Effects of } \\
\text { Continuous Variables }\end{array}$ & $\begin{array}{l}\text { Marginal } \\
\text { Effect }\end{array}$ & $\begin{array}{l}\text { Standard } \\
\text { Error }^{a}\end{array}$ & $\begin{array}{c}\text { Marginal } \\
\text { Effect }\end{array}$ & $\begin{array}{l}\text { Standard } \\
\text { Error }^{a} \\
\end{array}$ & $\begin{array}{l}\text { Marginal } \\
\text { Effect }\end{array}$ & $\begin{array}{l}\text { Standard } \\
\text { Error }^{a} \\
\end{array}$ \\
\hline Payment Reductions & $-0,00036$ & 0,00001 & $-0,00035$ & 0,00001 & $-0,00037$ & 0,00001 \\
\hline Amount of Full Benefits & 0,00042 & 0,00004 & 0,00046 & 0,00004 & 0,00038 & 0,00004 \\
\hline Unemployment Rate & 0,06756 & 0,00388 & 0,07132 & 0,00383 & 0,06244 & 0,00384 \\
\hline
\end{tabular}

Note: ${ }^{a}$ Standard errors were bootstrapped with 80 draws from the original sample.

Source: Versicherungskontenstichprobe 2002, own calculations. 
Table 1b Effects of Covariates on Transistion Rates Out Of Employment

\begin{tabular}{|c|c|c|c|c|c|c|}
\hline & \multicolumn{2}{|c|}{ Logit } & \multicolumn{2}{|c|}{ Probit } & \multicolumn{2}{|c|}{ Proportional Hazard } \\
\hline $\begin{array}{l}\text { Average Predicted } \\
\text { Transition Rate Out Of }\end{array}$ & \multicolumn{2}{|c|}{0,01538} & \multicolumn{2}{|c|}{0,01538} & \multicolumn{2}{|c|}{0,01529} \\
\hline $\begin{array}{l}\text { Average Effect of Changes } \\
\text { in Dummy Variables }\end{array}$ & Effect & $\begin{array}{l}\text { Standard } \\
\text { Error }^{a}\end{array}$ & Effect & $\begin{array}{l}\text { Standard } \\
\text { Error }^{a}\end{array}$ & Effect & $\begin{array}{l}\text { Standard } \\
\text { Error }^{a}\end{array}$ \\
\hline Individual... & & & & & & \\
\hline comes from East Germany & 0,00675 & 0,00028 & 0,00736 & 0,00028 & 0,00648 & 0,00028 \\
\hline is a foreigner & $-0,00274$ & 0,00031 & $-0,00249$ & 0,00032 & $-0,00278$ & 0,00031 \\
\hline has children & 0,00074 & 0,00033 & 0,00067 & 0,00034 & 0,00074 & 0,00033 \\
\hline is female & 0,00343 & 0,00041 & 0,00203 & 0,00039 & 0,00379 & 0,00042 \\
\hline faces health problems & 0,00997 & 0,00049 & 0,01013 & 0,00048 & 0,00976 & 0,00049 \\
\hline $\begin{array}{l}\text { Average Marginal Effects of } \\
\text { Continuous Variables }\end{array}$ & $\begin{array}{c}\text { Marginal } \\
\text { Effect }\end{array}$ & $\begin{array}{l}\text { Standard } \\
\text { Error }^{a} \\
\end{array}$ & $\begin{array}{c}\text { Marginal } \\
\text { Effect }\end{array}$ & $\begin{array}{l}\text { Standard } \\
\text { Error }^{a} \\
\end{array}$ & $\begin{array}{l}\text { Marginal } \\
\text { Effect }\end{array}$ & $\begin{array}{l}\text { Standard } \\
\text { Error }^{a} \\
\end{array}$ \\
\hline Payment Reductions & $-0,01188$ & 0,00085 & $-0,01279$ & 0,00089 & $-0,01170$ & 0,00084 \\
\hline Amount of Full Benefits & 0,00000 & 0,00001 & $-0,00001$ & 0,00001 & 0,00000 & 0,00001 \\
\hline Unemployment Rate & 0,02878 & 0,00098 & 0,03447 & 0,00102 & 0,02507 & 0,00092 \\
\hline
\end{tabular}

Note: ${ }^{a}$ Standard errors were bootstrapped with 80 draws from the original sample.

Source: Versicherungskontenstichprobe 2002, own calculations. 
Table 2 Total Effects of the Reform On Transition Rates by Gender

Men

\begin{tabular}{|c|c|c|c|c|c|c|c|}
\hline & \multicolumn{2}{|c|}{ Logit } & \multicolumn{2}{|c|}{ Probit } & \multicolumn{2}{|c|}{ Proportional Hazard } \\
\hline & & $\begin{array}{c}\text { Average } \\
\text { Predicted } \\
\text { Transition } \\
\text { Rates } \\
\end{array}$ & $\begin{array}{l}\text { Standard } \\
\text { Error }^{a}\end{array}$ & $\begin{array}{c}\text { Average } \\
\text { Predicted } \\
\text { Transition } \\
\text { Rates } \\
\end{array}$ & $\begin{array}{l}\text { Standard } \\
\text { Error }^{a}\end{array}$ & $\begin{array}{c}\text { Average } \\
\text { Predicted } \\
\text { Transition } \\
\text { Rates } \\
\end{array}$ & $\begin{array}{l}\text { Standard } \\
\text { Error }^{a}\end{array}$ \\
\hline $\begin{array}{l}\text { Transitions } \\
\text { into } \\
\text { Retirement }\end{array}$ & $\begin{array}{l}\text { Before } \\
\text { Reform } \\
\text { After } \\
\text { Reform }\end{array}$ & $\begin{array}{l}0,05295 \\
0,03176\end{array}$ & 0,00112 & $\begin{array}{l}0,05255 \\
0,03197\end{array}$ & 0,00115 & $\begin{array}{l}0,05257 \\
0,03198\end{array}$ & 0,00112 \\
\hline $\begin{array}{l}\text { Transitions } \\
\text { out of } \\
\text { Employment }\end{array}$ & $\begin{array}{l}\text { Before } \\
\text { Reform } \\
\text { After } \\
\text { Reform }\end{array}$ & $\begin{array}{l}0,01804 \\
0,01482\end{array}$ & 0,00103 & $\begin{array}{l}0,01814 \\
0,01345\end{array}$ & 0,00094 & $\begin{array}{l}0,01792 \\
0,01533\end{array}$ & 0,00107 \\
\hline
\end{tabular}

Women

\begin{tabular}{|c|c|c|c|c|c|c|c|}
\hline & \multicolumn{2}{|c|}{ Logit } & \multicolumn{2}{|c|}{ Probit } & \multicolumn{2}{|c|}{ Proportional Hazard } \\
\hline & & $\begin{array}{c}\text { Average } \\
\text { Predicted } \\
\text { Transition } \\
\quad \text { Rates }\end{array}$ & $\begin{array}{l}\text { Standard } \\
\text { Error }^{a}\end{array}$ & $\begin{array}{c}\text { Average } \\
\text { Predicted } \\
\text { Transition } \\
\text { Rates }\end{array}$ & $\begin{array}{l}\text { Standard } \\
\text { Error }^{a}\end{array}$ & $\begin{array}{c}\text { Average } \\
\text { Predicted } \\
\text { Transition } \\
\text { Rates }\end{array}$ & $\begin{array}{c}\text { Standard } \\
\text { Error }^{a}\end{array}$ \\
\hline $\begin{array}{l}\text { Transitions } \\
\text { into } \\
\text { Retirement }\end{array}$ & $\begin{array}{l}\text { Before } \\
\text { Reform } \\
\text { After } \\
\text { Reform } \\
\end{array}$ & $\begin{array}{l}0,13816 \\
0,02901\end{array}$ & 0,00275 & $\begin{array}{l}0,13910 \\
0,02508\end{array}$ & 0,00267 & $\begin{array}{l}0,13803 \\
0,03065\end{array}$ & 0,00279 \\
\hline $\begin{array}{l}\text { Transitions } \\
\text { out of } \\
\text { Employment }\end{array}$ & $\begin{array}{l}\text { Before } \\
\text { Reform } \\
\text { After } \\
\text { Reform }\end{array}$ & $\begin{array}{l}0,01458 \\
0,01385\end{array}$ & 0,00050 & $\begin{array}{l}0,01492 \\
0,01320\end{array}$ & 0,00046 & $\begin{array}{l}0,01424 \\
0,01412\end{array}$ & 0,00050 \\
\hline
\end{tabular}

Note: ${ }^{a}$ Standard errors of the difference between the predicted transition rates. The standard errors were bootstrapped with 80 draws from the original sample.

Source: Versicherungskontenstichprobe 2002, own calculations. 
Table 3 Total Effects of the Reform on the Expected Duration Until Retirement Entry and Employment Exit

\begin{tabular}{|c|c|c|c|c|c|c|c|c|c|}
\hline & \multicolumn{9}{|c|}{$\begin{array}{l}\text { Expected Duration Until Retirement Entry } \\
\text { (from the First Month of Eligibility for Benefits) } \\
\text { Before and After the Reform by Sub-Samples (in Months) }\end{array}$} \\
\hline & \multicolumn{3}{|c|}{ After Reform } & \multicolumn{3}{|c|}{ Before Reform } & \multicolumn{3}{|c|}{ Difference } \\
\hline & Logit & Probit & $\begin{array}{l}\text { Propor- } \\
\text { tional } \\
\text { Hazards }\end{array}$ & Logit & Probit & $\begin{array}{l}\text { Propor- } \\
\text { tional } \\
\text { Hazards }\end{array}$ & Logit & Probit & $\begin{array}{l}\text { Propor- } \\
\text { tional } \\
\text { Hazards }\end{array}$ \\
\hline Full Sample & 28,42 & 28,77 & 27,67 & 13,25 & 13,3 & 13,32 & 15,16 & 15,45 & 14,35 \\
\hline Men & 27,32 & 27,18 & 27,12 & 16,98 & 17,1 & 17,08 & 10,34 & 10,05 & 10,04 \\
\hline Women & 34,78 & 38,29 & 33,53 & 6,56 & 6,39 & 6,59 & 28,23 & 31,90 & 26,94 \\
\hline $\begin{array}{l}\text { Men (West } \\
\text { Germany) }\end{array}$ & 27,74 & 27,63 & 27,46 & 18,89 & 19 & 19,04 & 8,85 & 8,60 & 8,42 \\
\hline $\begin{array}{l}\text { Men (East } \\
\text { Germany) }\end{array}$ & 23,73 & 23,77 & 22,78 & 10,81 & 10,9 & 10,54 & 12,92 & 12,83 & 12,24 \\
\hline \multicolumn{10}{|c|}{ Men (West Germany) by Quintiles of Benefit Claims at Age 60: } \\
\hline 1st Quintile & 37,81 & 38,47 & 37,63 & 22,44 & 22,3 & 22,58 & 15,37 & 16,20 & 15,05 \\
\hline 2nd Quintile & 27,54 & 27,57 & 26,95 & 16,46 & 16,8 & 16,37 & 11,08 & 10,82 & 10,58 \\
\hline 3rd Quintile & 24,49 & 24,47 & 24,16 & 16,64 & 16,7 & 16,72 & 7,85 & 7,74 & 7,44 \\
\hline 4th Quintile & 22,00 & 21,49 & 21,84 & 16,76 & 17,1 & 16,68 & 5,24 & 4,44 & 5,16 \\
\hline 5th Quintile & 23,57 & 23,87 & 23,27 & 24,67 & 24,7 & 24,79 & $-1,10$ & $-0,81$ & $-1,52$ \\
\hline \multicolumn{10}{|c|}{$\begin{array}{l}\text { Expected Duration Until Employment Exit (from the age of 55) } \\
\text { Before and After the Reform by Sub-Samples (in Months) }\end{array}$} \\
\hline \multicolumn{4}{|c|}{ After Reform } & \multicolumn{3}{|c|}{ Before Reform } & \multicolumn{3}{|c|}{ Difference } \\
\hline & Logit & Probit & $\begin{array}{c}\text { Propor- } \\
\text { tional } \\
\text { Hazards }\end{array}$ & Logit & Probit & $\begin{array}{c}\text { Propor- } \\
\text { tional } \\
\text { Hazards }\end{array}$ & Logit & Probit & $\begin{array}{c}\text { Propor- } \\
\text { tional } \\
\text { Hazards }\end{array}$ \\
\hline Full Sample & 65,85 & 67,92 & 64,58 & 56,39 & 56 & 56,34 & 9,45 & 11,93 & 8,24 \\
\hline Men & 67,07 & 68,83 & 66,35 & 59,45 & 58,7 & 60,14 & 7,62 & 10,16 & 6,21 \\
\hline Women & 56,27 & 59,61 & 55,12 & 51,79 & 51,7 & 51,91 & 4,48 & 7,89 & 3,21 \\
\hline $\begin{array}{l}\text { Men (West } \\
\text { Germany) }\end{array}$ & 69,59 & 70,97 & 68,86 & 64,14 & 63,6 & 64,77 & 5,45 & 7,42 & 4,09 \\
\hline $\begin{array}{l}\text { Men (East } \\
\text { Germany) }\end{array}$ & 60,35 & 62,08 & 59,56 & 42,58 & 42,1 & 42,25 & 17,76 & 19,99 & 17,31 \\
\hline \multicolumn{10}{|c|}{ Men (West Germany) by Quintiles of Benefit Claims at Age 60: } \\
\hline 1st Quintile & 70,11 & 71,79 & 69,05 & 66,35 & 65,9 & 66,87 & 3,76 & 5,89 & 2,18 \\
\hline 2nd Quintile & 67,26 & 68,74 & 65,95 & 60,01 & 59,2 & 59,72 & 7,25 & 9,58 & 6,23 \\
\hline 3rd Quintile & 69,97 & 71,36 & 69,1 & 59,46 & 58,9 & 59,74 & 10,51 & 12,50 & 9,36 \\
\hline 4th Quintile & 69,97 & 70,62 & 69,36 & 57,89 & 57,6 & 57,90 & 12,08 & 13,02 & 11,46 \\
\hline 5th Quintile & 68,56 & 70,1 & 67,75 & 71,05 & 70,6 & 70,18 & $-2,49$ & $-0,47$ & $-2,43$ \\
\hline
\end{tabular}

Source: Versicherungskontenstichprobe 2002, own calculations. 